\title{
Bioactivity of POPs and their effects in mosquitofish in Sydney Olympic Park, Australia
}

\author{
Christopher A. Rawson ${ }^{\text {a }}$, Louis A. Tremblay ${ }^{b}$, Michael St. J. Warne ${ }^{\text {, }}$, Guang-guo Ying ${ }^{\text {, }}$, Rai Kookana ${ }^{\mathrm{c}}$, \\ Edwina Laginestra ${ }^{\mathrm{d}, 1}$, John C. Chapman ${ }^{\mathrm{e}}$, Richard P. Lim ${ }^{\mathrm{a}}{ }^{*}$ \\ ${ }^{a}$ Institute of Water and Environmental Resource Management (IWERM) and Department of Environmental Sciences, University of Technology, Sydney (UTS), PO Box 123 Broadway, NSW, \\ 2001, Australia \\ ${ }^{\mathrm{b}}$ Landcare Research, PO Box 40, Lincoln 7616, New Zealand \\ c CSIRO, Centre for Environmental Contaminants Research, PMB 2, Glen Osmond SA, 5064, Australia \\ d Sydney Olympic Park Authority, Figtree Drive, Sydney Olympic Park, NSW, 2127, Australia \\ e Department of Environment and Climate Change, NSW, 59-61 Goulburn St. Sydney South, NSW, 1232, Australia
}

\begin{abstract}
a b s t r a c t
The site of the 2000 Olympic Games (Sydney Olympic Park (SOP), Sydney, Australia) was contaminated by persistent organic pollutants (POPs) prior to remediation in the 1990s. This study investigates the bioactivity of POPs in the sediment and water of wetlands across SOP by in vitro 2,3,7,8-TCDD equivalence (TCDDeq) measurement (H4IIE cell line bioassay). Further, it examines whether disturbance of these sediments is likely to mobilise ligands for this receptor into the water column. Exposure to aryl hydrocarbon receptor (AhR) ligands was measured in vivo using hepatic cytochrome P4501A (CYP1A) induction (EROD) in the mosquitofish (Gambusia holbrooki). Aqueous TCDDeq ranged from 0.013 to $0.057 \mathrm{pM}$ in SOP wetlands which was significantly ( $\mathrm{pb} 0.05$ ) less that in urban reference sites. These concentrations were not correlated to physical or chemical characteristics of the wetlands. In the sediments, TCDDeq ranged from 0.0016 to $7.06 \mu \mathrm{g} / \mathrm{kg}$ and these were not significantly $(p \geq 0.05)$ different to that measured in urban reference sites. Simulated disturbance of

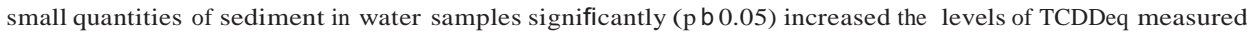
in the water. Sediment TCDDeq was correlated to sediment $\Sigma$ PAH concentration in 2006 and sediment $\Sigma$ PCB, ¿DDT concentrations and fine sediment grain size in 2005. While fish at one SOP wetland had hepatic EROD activity elevated above the estimated basal level for this species, these were at the lower end of the range measured in urban impacted, non-remediated wetlands. EROD activity was positively correlated with both the sediment $\Sigma$ PCB load and aqueous TCDDeq. Increased catchment size was correlated with increased EROD activity suggesting an even spread of POPs throughout the residential areas of the Sydney metropolitan area. The concentration of bioactive POPs in the wetlands of SOP is therefore low relative to urban reference sites demonstrating the ongoing success of the remediation program.
\end{abstract}

\section{Introduction}

Sydney Olympic Park (SOP) was highly contaminated with commercial, industrial and domestic wastes prior to its remediation in the 1990s in the lead up to the Sydney 2000 Olympic and Paralympic Games. Amongst the persistent organic pollutants (POPs) found at the site were organochlorine pesticides (OCPs), polychlorinated biphenyls (PCBs), polychlorinated dibenzo-p-dioxins (PCDDs or dioxins) and polycyclic aromatic hydrocarbons (PAHs) (Laginestra et al., 2001) (Table 1). Exposure to POPs can cause major physiological damage through carcinogenic, teratogenic, and genotoxic mechanisms and has been shown to cause reproductive impairment at low concentrations (reviewed by Delzell et al., 1994a,b,c). At SOP their sources were from

\footnotetext{
* Corresponding author. Tel.: +61 29514 4037; fax: +612 05144079.

E-mail address: Richard.Lim@uts.edu.au (R.P. Lim).

${ }^{1}$ Current Address: Graduate School of the Environment, Macquarie University, North Ryde, NSW, 2109, Australia.
}

industrial processes including chemical manufacture (Rubenstein and Wicklund, 1991) and uncontrolled industrial and municipal dumping (Waste Services NSW, 1994). In particular, the herbicides 2,4-D and 2,4,5-T (the active ingredients of 'Agent Orange' of which 2,3,7,8-TCDD is both a by-product and contaminant (Barsotti et al., 1979)), PCBs and phenols were manufactured adjacent to the site (Rubenstein and Wicklund, 1991). As part of the remediation process, soils and sediments with a total concentration of 'scheduled compounds' (including OCPs and PCBs) greater than 2 ppm were treated by thermal desorption and base-catalysed decomposition in an on-site facility.

Four hundred tonnes of scheduled chemical waste were excavated, treated and combined with non-treated excavated material in large containment mounds. The containment mounds were clay-capped and geotextile-lined to avoid infiltration and leaching of contaminants to the groundwater (OCA, 1997; OCA and ADI, 1999). Leachate drains were installed and their contents have been reported to contain measurable levels of POPs (e.g., SKM and EVS, 2001). The remediation established terrestrial and aquatic habitats throughout SOP, which are 
Table 1

Organic compounds found in Sydney Olympic Park groundwater, surface waters and sediments samples prior to remediation and leachate from containment mounds post-remediation with $\log \mathrm{K}_{\mathrm{ow}}$.

\begin{tabular}{|c|c|c|c|c|c|}
\hline Compound & $\begin{array}{l}\text { Groundwater } \\
(\mu \mathrm{g} / \mathrm{L})\end{array}$ & $\begin{array}{l}\text { Sediment } \\
(\mu \mathrm{g} / \mathrm{Kg})\end{array}$ & $\begin{array}{l}\text { Surface Water } \\
(\mu \mathrm{g} / \mathrm{L})\end{array}$ & $\begin{array}{l}\text { Leachate } \\
(\mu \mathrm{g} / \mathrm{L})\end{array}$ & $\log K_{o w}$ \\
\hline$\overline{\mathrm{TPH}^{\mathrm{a}}}$ & $1,025,000$ & $30,000,000^{b}$ & $1 \times 10^{6}$ & $6,159,000$ & \\
\hline Total PAH & 182,200 & 430,800 & 43 & 5763 & $3.35^{c}$ \\
\hline Benzo(a)pyrene & 4900 & 28,000 & 30 & 33.4 & 6.35 \\
\hline Benzene & 92,000 & 300 & 160,000 & 77,848 & 2.03 \\
\hline Toluene & 58,000 & 200 & 150 & 3740 & 2.73 \\
\hline Ethylbenzene & 4600 & 26,000 & 4800 & 1920 & 3.15 \\
\hline Xylene & 5357 & 2000 & 52 & 1301 & 3.12 \\
\hline Phenolics & 82,700 & 19,600 & 50 & 1171 & 5.76 \\
\hline $\begin{array}{l}\text { Total dioxins/furans } \\
\text { TCDDeq }\end{array}$ & 5.8 & $316,258^{b}$ & $\begin{array}{l}\mathrm{b} 2 \\
0.246^{\mathrm{b}}\end{array}$ & $\begin{array}{l}1.3 \times 10^{-10} \\
0.000176\end{array}$ & \\
\hline TCDD & 0.0092 & $190^{\mathrm{b}}$ & $0.232^{\mathrm{b}}$ & 0.000029 & 6.42 \\
\hline Total PCB & b0.03 & 14000 & $10140^{\mathrm{b}}$ & b 0.01 & $\begin{array}{l}4.51^{\mathrm{d}}- \\
7.88^{\mathrm{e}}\end{array}$ \\
\hline Total OCP & b 600 & 1500 & $6800^{\mathrm{b}}$ & b 0.02 & \\
\hline DDT & b 40 & 700 & $446^{\mathrm{b}}$ & ND & $6.8^{\mathrm{f}}$ \\
\hline DDE & b40 & 1500 & $744^{\mathrm{b}}$ & ND & $6.9^{f}$ \\
\hline DDD & b 40 & 16000 & $1044^{\mathrm{b}}$ & ND & $6.2^{f}$ \\
\hline Organophosphates & 2700 & 180 & ND & ND & b $1-5.5^{f, g}$ \\
\hline
\end{tabular}

Unless otherwise specified, data was sourced from the Sydney Olympic Park Ecology Databank. ND = No Data.

a Total Petroleum Hydrocarbons.

b Results from estuarine samples from Homebush Bay and Parramatta River.

c Value for naphthalene.

d Minimum reported value (PCB1) (Hansen et al., 1999).

e Maximum reported value (PCB209)(Hansen et al., 1999).

f Finizio et al., 1997.

g Maximum reported value for jodfenphos.

now habitat for a variety of wildlife including migratory birds and the endangered green and golden bell frog (Litoria aurea) (OCA, 2000). Given the current high ecological value of SOP, it is essential that the monitoring of the presence of POPs is continued.

A common method for the remediation of contaminated sediment is removal by dredging. Previous work has suggested that migration and increased bioavailability of contaminants may occur as a result of such disturbance (Rice and White, 1987; Latimer et al., 1999). In SOP, wetlands designed to intercept urban contaminated sediments (by settlement in ponded areas) may require future alterations to deal with reductions in stream/pond depth. The eastern shore of Homebush Bay, a heavily POP contaminated site (Birch et al., 2007), is currently subject to remediation by sediment dredging and treatment by directly heated thermal desorption. It is important that the potential of these processes to increase the bioavailability of sediment-bound contaminants be assessed and relayed to site managers.

Planar, aromatic hydrocarbons (including PCBs, PAHs, PCDD/Fs and some OCPs) are high affinity ligands for the endogenous aryl hydrocarbon receptor (AhR) (Denison and Heath-Pagliuso, 1998; Sierra-Santoyo et al., 2000; Oropeza-Hernandez et al., 2003). The AhR/ligand complex modulates expression of the $1 \mathrm{~A}$ family of cytochrome P450 mRNA (CYP1AmRNA), which translates to CYP1A, a xenobiotically active enzyme present in many taxa (Hahn, 1998). While the direct toxicological implications of small increases in CYP1A concentrations are relatively minor (e.g., CYP1A metabolism of xenobiotics can lead to oxidative stress (Nebert et al., 2000; Dalton et al., 2002)), the induction of CYP1A above background levels has been used (in vitro and in vivo) as a biomarker for exposure to POPs (see Whyte et al., 2000, 2004 for reviews).

Previous studies (Ying et al., in preparation) have shown that PCBs, PAHs, DDT and dioxins are present in the sediments of SOP wetlands. The current study investigated the potential biological effects of these compounds by 1 . quantifying their affinity for the AhR in aqueous and sediment fractions of the wetlands in SOP and urban-impacted reference sites; 2. assessing the potential for sediment bound POPs to be remobilized through anthropogenic disturbance (e.g., dredging); and 3. examining the exposure of mosquitofish, (Gambusia holbrooki, Poeciliidae) inhabiting the wetlands of SOP to POPs using EROD activity as a biomarker of exposure. It was anticipated that the results would provide important information regarding the success of the remediation program in closing pre-remediation contaminant pathways.

\section{Materials and methods}

\subsection{Study sites}

Three sets of study sites were selected for study: 1) nine SOP wetlands to cover a range of surface water catchments, contamination and remediation histories, 2) four unremediated sites from the adjacent Parramatta River with a known contamination history, and 3) eighteen urban impacted wetlands across the Sydney metropolitan area a geographically diverse range of urban impacted wetlands. These reference sites were selected to provide a baseline representing wetlands subject to urban impacts such as aerial deposition of industrial products and catchment runoff.

\subsection{Water and sediment sample collection}

Duplicate water samples were collected in washed and solvent (methanol and dichloromethane) rinsed amber glass bottles $\left(\begin{array}{ll}1 & L\end{array}\right)$ with Teflon-lined lids and transported on ice to the laboratory where they were stored at $4{ }^{\circ} \mathrm{C}$ for no more than $48 \mathrm{~h}$ prior to extraction. Composite sediment grab samples from the top $5 \mathrm{~cm}$ of the sediment over an area of approximately $225 \mathrm{~m}^{2}$, were collected using a $10 \mathrm{~cm}$ diameter grab sampler and sieved (2-mm mesh) on-site.

\subsection{Sediment disturbance experiment}

Water:sediment (30 g:1 L) suspensions were prepared for seven study sites (i.e., Boundary Creek, Eastern Water Quality Control Pond (EWQCP), Southern Water Quality Control Pond (SWQCP), Northern Water Feature, Bicentennial Park., Narrawang 22 and Macquarie University) using both field and reverse osmosis (RO) water. Suspensions were allowed to settle for 1 week then orbitally shaken for $48 \mathrm{~h}$ and centrifuged $(1710 \times \mathrm{g}, 20 \mathrm{~min})$, after which the supernatant was collected for extraction.

\subsection{Sample extraction and elution}

Aqueous samples were filtered (1.2 $\mu \mathrm{m}, \mathrm{GFC})$ and POPs extracted onto C18 Empore disks. Disks were air dried $(1 \mathrm{~h})$ and stored at $-20{ }^{\circ} \mathrm{C}$ for a maximum of 28 days before elution. The disks were thawed and dried on a drying plate for $1 \mathrm{~h}$ at $40{ }^{\circ} \mathrm{C}$, twice eluted with $10 \mathrm{ml}$ dichloromethane (DCM) and solvent exchanged under a nitrogen gas stream to $500 \mu \mathrm{L}$ DMSO for storage at $-80{ }^{\circ} \mathrm{C}$.

Wet sediment sub-samples $(500 \mathrm{ml})$ were freeze-dried for one week and POPs extracted with DCM using a Dionex ASE300 Accelerated Solvent Extractor (ASE). Five grams of each sample were weighed into each extraction cell having a filter pad at the bottom and the cell was filled up using diatomaceous earth from Dionex. The ASE used an oven temperature of $100{ }^{\circ} \mathrm{C}$ with $10 \mathrm{MPa}$ (1500 psi) pressure. The heat-up time was $5 \mathrm{~min}$ and the static time was 5 min for 2 cycles. The extracts were concentrated in collection bottles under nitrogen gas using a Dionex SE500 Solvent Evaporator. Final extracts were redissolved in $1 \mathrm{ml}$ of hexane. Some dirty extracts were further cleaned up using solid phase extraction (SPE) silica cartridges. Extracts were stored at $-80{ }^{\circ} \mathrm{C}$ prior to analysis. 


\subsection{H4IIE bioassay}

Tissue culture and H4IIE bioassay methods were adapted from a review of published protocols by Whyte et al. (2004). A culture of H4IIE rat hepatoma cells was maintained in Dulbecco's Modified Eagles Media (500 ml DMEM (Gibco), 25 ml Foetal Bovine Serum (Gibco), $10 \mathrm{ml} \mathrm{L-glutamine} \mathrm{(Gibco),} 1.25 \mathrm{ml}$ Gentamycin (Gibco), $0.5 \mathrm{ml} 2.5 \mathrm{M}$ HEPES (Sigma-Aldrich)) at $37{ }^{\circ} \mathrm{C}$ and $5 \% \mathrm{CO}_{2}$. For the bioassay H4IIE cells were incubated in 96 well tissue culture treated plates $\left(2 \times 10^{4}\right.$ cells/well) for $24 \mathrm{~h}\left(37{ }^{\circ} \mathrm{C}\right.$ and $\left.5 \% \mathrm{CO}_{2}\right)$. Sample dilutions ( $\left.1 \mu \mathrm{L}\right)$ were added to each well and incubated for a further $24 \mathrm{~h}\left(37{ }^{\circ} \mathrm{C}\right.$ and $\left.5 \% \mathrm{CO}_{2}\right)$ with a 2,3,7,8-TCDD (AccuStandard: Lot B4010226) (5 to $0.02 \mathrm{nM}$ ) standard curve on each plate. After $24 \mathrm{~h}$ the plates were washed with phosphate buffered saline (PBS) and $100 \mu \mathrm{L}$ of 7-ethoxyresorufin (7-ER) (Sigma-Aldrich) (2 $\mu \mathrm{M}$ in methanol) added to each well. The rate of conversion to the fluorescent endpoint, resorufin, was read (ex: $540 \mathrm{~nm}$, em: $590 \mathrm{~nm}$, BMG Fluostar Optima) using continuous readings over $30 \mathrm{~min}$. The maximum rate of resorufin production was calculated using a resorufin standard curve, and the protein content of each well was quantified using a bicinchoninic acid protein assay (Pierce MicroBCA Protein Kit). Each EC50 value (pmoles resorufin $/ \mathrm{min} / \mathrm{mg}$ protein) was compared with that of the standard curve giving a value for TCDD equivalency (TCDDeq) (pM).

\subsection{Fish collection and processing}

Mosquitofish were periodically collected using dip nets between May 2006 and February 2007 from four wetlands in SOP (Boundary Creek, Narrawang 22, Lake Belvedere and EWQCP) and two reference sites (Macquarie University and Upper Colo) and from a further nine study sites across the Sydney metropolitan area in February 2007. Individual fish were weighed and photographed using a digital camera mounted on a dissecting microscope. The external morphology of each individual was used to classify it as adult male (fully developed gonopodium with a gonopodial terminal hook complex), juvenile male (evidence of gonopodial development but no gonopodial terminal hook complex), adult female (presence of lateral abdominal black spot) or juvenile female (absence of gonopodial development and absence of lateral abdominal black spot). Fish were sacrificed by immersion in benzocaine $(400 \mathrm{mg} / \mathrm{L})$ and gill, liver and gonad (adult male only) tissue removed and stored in microfuge tubes at $-80{ }^{\circ} \mathrm{C}$.

\subsection{CYP1A induction (EROD activity)}

Methods for determining EROD activity were adapted from the Eggens and Galgani (1992) modifications to the methods of Burke and Mayer (1974) for high sample throughput using a fluorescence platereader. With low tissue quantities obtained from mosquitofish (liver mass approximately $0.01 \mathrm{~g}$ ) it was necessary to use the entire liver, gill and gonad tissue of each individual. Tissues were thawed on ice and mechanically homogenised in PBS. Homogenates were centrifuged at $10,000 \times \mathrm{g}\left(4{ }^{\circ} \mathrm{C}, 20 \mathrm{~min}\right)$ and the supernatant (S9 fraction) removed. The S9 fractions $(25 \mu \mathrm{l})$ were added in quadruplicate to a 96 well plate with $75 \mu$ l HEPEs buffer (0.12 M HEPEs, $5 \mathrm{mM} \mathrm{MgCl}_{2} \cdot 6 \mathrm{H}_{2} \mathrm{O}, \mathrm{pH}=7.8$ ) and $80 \mu \mathrm{l}$ of 7-ER $(3.8 \mu \mathrm{M})$. Immediately prior to reading, $20 \mu \mathrm{l} \mathrm{NADPH}$ $(247 \mu \mathrm{M})$ was added to each well of the plate and the maximum rate of generation of resorufin (EROD activity), measured (ex: $540 \mathrm{~nm}$, em: $590 \mathrm{~nm}, 37^{\circ} \mathrm{C}, 30 \mathrm{~min}$, BMG Fluostar Optima) and standardised against its protein concentration (Pierce BCA Protein Kit). To verify the comparability of the results over time, silver bream (Acanthropagrus australis) liver samples were analysed for EROD activity prior to the conduct of each assay run. EROD activity in these reference livers did not vary statistically ( $p \geq 0.05$ ) from prior to the first assay run to prior to the final assay run.

\subsection{Data analyses}

Differences between the TCDDeq at groups of study sites (SOP wetlands and reference sites) and before and after disturbance with sediment were analysed using single-factor ANOVA. EROD activities were compared using a 2-factor (site, collection time) ANOVA. The EROD activity in mosquitofish collected from SOP and reference wetlands in February 2007 were compared using a single-factor ANOVA (site). Where the assumption of equal variances was not met data were log transformed and Tukeys pairwise comparisons were run as post hoc tests. Multiple regressions were used to examine relationships between in vitro TCDDeq and the physical (grain size) and chemical characteristics ( $\Sigma \mathrm{PCB}, \Sigma \mathrm{PAH}, \Sigma \mathrm{DDT}, \mathrm{pH}, \mathrm{CaCl}_{2} \mathrm{pH}$, conductivity, redox potential, organic carbon content) of the sediment. The TCDDeq of the water samples after disturbance with sediment was analysed using the same predictors but with the addition of aqueous and sediment TCDDeq. Multiple regressions were also used to examine the influence of two sets of site-specific environmental factors (aqueous and sediment TCDDeq, $\Sigma$ PCB, $\Sigma$ DDT, $\Sigma$ PAH, organic carbon, inorganic carbon and black carbon - sediment grain size, $\mathrm{pH}$, conductivity, redox potential average water temperature and diurnal temperature range), which may influence the EROD activity in the

Table 2

Results of chemical analysis by Ying et al. (in prep) on sediments in Sydney Olympic Park, Parramatta Riverand urban reference study sites in 2005 and 2006.

\begin{tabular}{|c|c|c|c|c|c|c|c|}
\hline & & \multicolumn{3}{|l|}{2005} & \multicolumn{3}{|l|}{2006} \\
\hline & & $\begin{array}{l}\text { PAHs } \\
\text { (ng/g) }\end{array}$ & $\begin{array}{l}\sum \text { PCBs } \\
\text { (ng/g) }\end{array}$ & $\begin{array}{l}\sum \mathrm{DDT} \\
\text { (ng/g) }\end{array}$ & $\begin{array}{l}\text { PAHs } \\
\text { (ng/g) }\end{array}$ & $\begin{array}{l}\sum \mathrm{PCBs} \\
\text { (ng/g) }\end{array}$ & $\begin{array}{l}\sum \mathrm{DDT} \\
\text { (ng/g) }\end{array}$ \\
\hline \multirow{9}{*}{$\begin{array}{l}\text { Wetlands in Sydney } \\
\text { Olympic Park }\end{array}$} & Wharf Pond & 2550 & 15 & 12 & 1704 & 14 & 25 \\
\hline & $\begin{array}{l}\text { Bicentennial } \\
\text { Park }\end{array}$ & 5336 & 14 & 13 & 4309 & 11 & 19 \\
\hline & EWQCP & 14461 & 21 & 19 & 4269 & 20 & 29 \\
\hline & Wharf Stream & 2905 & 24 & 13 & ND & ND & ND \\
\hline & $\begin{array}{l}\text { Nth water } \\
\text { feat. }^{\text {a }}\end{array}$ & 1960 & 14 & 15 & 2808 & 12 & 21 \\
\hline & SWQCP & 1146 & 23 & 4 & 804 & 14 & 98 \\
\hline & Boundary Ck & 3409 & 33 & 24 & 1516 & 47 & 45 \\
\hline & Narrawang 22 & ND & ND & ND & 272 & 11 & 25 \\
\hline & Fishway & ND & ND & ND & 1265 & 5 & 20 \\
\hline \multirow[t]{5}{*}{$\begin{array}{l}\text { Parramatta River } \\
\text { sites }\end{array}$} & $\begin{array}{l}\text { Homebush } \\
\text { Bay }\end{array}$ & 11714 & 112 & 187 & 7628 & 175 & 55 \\
\hline & Haslams & 13085 & 124 & 109 & 7881 & 108 & 10 \\
\hline & Mouth & & & & & & \\
\hline & Silverwater $\mathrm{Br}$ & 3701 & 14 & 31 & 19358 & 62 & 53 \\
\hline & $\begin{array}{l}\text { Newington } \\
\text { Wf }\end{array}$ & 10251 & 62 & 106 & 1256 & 16 & 43 \\
\hline \multirow{19}{*}{$\begin{array}{l}\text { Urban impacted } \\
\text { wetlands }\end{array}$} & Bardwell Ck & & & & 6608 & 17 & 40 \\
\hline & Galston & & & & 84 & 8 & 21 \\
\hline & Second Ponds & & & & 2343 & 32 & 44 \\
\hline & $\begin{array}{l}\text { Ck } \\
\text { Narrabeen }\end{array}$ & & & & 218 & 8 & 16 \\
\hline & Moores Ck & & & & 2514 & 18 & 17 \\
\hline & Quakers Hill & & & & 312 & 12 & 17 \\
\hline & $\begin{array}{l}\text { Yarramundi } \\
\text { Lagoon }\end{array}$ & & & & 4590 & 19 & 30 \\
\hline & Eastern Ck & & & & 988 & 20 & 16 \\
\hline & Kemps Ck & & & & 107 & 9 & 15 \\
\hline & $\begin{array}{l}\text { Chipping } \\
\text { Norton Lake }\end{array}$ & & & & 38 & 13 & 6 \\
\hline & South Ck & & & & 555 & 17 & 37 \\
\hline & $\begin{array}{l}\text { Joseph Banks } \\
\text { Park }\end{array}$ & & & & 34 & 4 & 10 \\
\hline & Oyster Bay & & & & 1212 & 10 & 23 \\
\hline & Cecil Hills & & & & 327 & 5 & 21 \\
\hline & Terrys Ck & & & & 645 & 16 & 31 \\
\hline & Georges River & & & & 1898 & 85 & 25 \\
\hline & Macquarie & & & & 452 & 14 & 33 \\
\hline & Univ. & & & & & & \\
\hline & Nepean River & & & & 1246 & 3 & 10 \\
\hline
\end{tabular}

All values for sediment concentrations are expressed per gram dry weight. $\mathrm{ND}=$ no data collected.

a Northern water feature. 
Table 3

TCDDeq values for surface water and sediments of Sydney Olympic Park and Homebush Bay and urban impacted wetlands measured using the H4IIE cell line bioassay in 2005 and 2006.

\begin{tabular}{|c|c|c|c|c|c|}
\hline & & \multicolumn{2}{|l|}{2005} & \multicolumn{2}{|l|}{2006} \\
\hline & & $\begin{array}{l}\text { Water } \\
\text { TCDDeq } \\
\text { (pM) }\end{array}$ & $\begin{array}{l}\text { Sediment } \\
\text { TCDDeq } \\
(\mu \mathrm{g} / \mathrm{kg})\end{array}$ & $\begin{array}{l}\text { Water } \\
\text { TCDDeq } \\
(\mathrm{pM})\end{array}$ & $\begin{array}{l}\text { Sediment } \\
\text { TCDDeq } \\
(\mu \mathrm{g} / \mathrm{kg})\end{array}$ \\
\hline \multirow{10}{*}{$\begin{array}{l}\text { Wetlands in Sydney } \\
\text { Olympic Park }\end{array}$} & Wharf pond & ND & 0.0228 & ND & 1.39 \\
\hline & Bicentennial Park & 0.0226 & 2.22 & 0.0157 & 7.06 \\
\hline & EWQCP & 0.0213 & 0.402 & 0.0218 & 4.58 \\
\hline & Wharf stream & ND & 0.689 & ND & ND \\
\hline & Nth water feat. ${ }^{a}$ & 0.0145 & 1.63 & 0.0193 & 4.21 \\
\hline & SWQCP & 0.0401 & 0.0158 & 0.0267 & 5.20 \\
\hline & Boundary Ck & 0.0576 & 3.52 & 0.0334 & 5.01 \\
\hline & Narrawang 22 & 0.0140 & ND & 0.0320 & 0.809 \\
\hline & Fishway & 0.0535 & ND & 0.0473 & 2.26 \\
\hline & Lake Belvedere & 0.0147 & ND & 0.0157 & ND \\
\hline \multirow[t]{4}{*}{ Parramatta River sites } & Newington Wharf & ND & 6.57 & ND & 5.01 \\
\hline & Homebush Bay & ND & 0.313 & ND & 22.0 \\
\hline & Haslams Mouth & ND & 81.7 & ND & 4.89 \\
\hline & Silverwater Bridge & ND & 0.210 & ND & 80.9 \\
\hline \multirow{19}{*}{$\begin{array}{l}\text { Urban impacted } \\
\text { reference sites }\end{array}$} & Bardwell Ck & & & 0.0564 & 9.16 \\
\hline & Galston Ck & & & 0.0348 & 0.359 \\
\hline & Second ponds Ck. & & & 0.0094 & 10.5 \\
\hline & Narrabeen Lake & & & 0.0245 & 1.23 \\
\hline & Moores Ck & & & 0.0548 & 12.9 \\
\hline & Quakers Hill & & & 0.0677 & 2.25 \\
\hline & Yarramundi Lagoon & & & 0.0086 & 4.95 \\
\hline & Eastern Ck & & & 0.0444 & 2.89 \\
\hline & Kemps Ck & & & 0.0499 & 0.131 \\
\hline & Chipping Norton Lk & & & 0.0497 & 0.00479 \\
\hline & South Ck & & & 0.0968 & 3.47 \\
\hline & Joseph Banks Park & & & 0.0263 & 0.0543 \\
\hline & Oyster Bay & & & 0.0706 & 8.94 \\
\hline & Cecil Hills & & & 0.0347 & 0.525 \\
\hline & Terrys Ck & & & 0.0267 & 4.29 \\
\hline & Georges River & & & 0.0367 & 8.96 \\
\hline & Nepean River & & & 0.0167 & 0.266 \\
\hline & Prospect Ck & & & 0.0954 & n/a \\
\hline & Macquarie Uni & 0.0384 & & 0.0312 & 6.65 \\
\hline Pristine Ref. ${ }^{b}$ & Upper Colo & 0.0070 & & 0.0056 & BDL \\
\hline
\end{tabular}

$\mathrm{ND}=$ no data, $\mathrm{BDL}=$ below assay detection limit.

a Northern water feature.

b Reference site outside urban influences

fish. All analyses were run using the SPSS statistical software (version 14.1, 2005) at $\alpha=0.05$.

\section{Results}

\subsection{Sediment chemistry}

The sediment chemistry of the SOP wetlands has been described in detail by Ying et al. (in preparation). Briefly, POP contamination was highest in the estuarine Parramatta River and Homebush Bay sites adjacent to SOP (Table 2). At these sites the levels of $\Sigma$ PAHs were regularly greater than twice those measured at the wetlands within SOP (Table 2). High sediment $\Sigma$ PAH concentrations were found in SOP wetlands at EWQCP in 2005 (14461 ng/g) and 2006 (4269 ng/g) and in Bicentennial Park in 2006 (4309 ng/g). ¿PCB levels in SOP wetlands ranged between 14 and 33 ng/g in 2005 and 11 and 47 ng/g in 2006. $\Sigma$ DDT concentrations in the SOP wetlands were below those in the estuarine sites except in SWQCP and Boundary Ck in 2006 (98 and $45 \mathrm{ng} / \mathrm{g}$, respectively). In general, the concentrations of POPs in the sediments of the SOP wetlands were within the range measured at urban-impacted reference wetlands. However, in 2005 EWQCP sediment had more than twice the concentration of $\Sigma \mathrm{PAHs}$ (14461 ng/g) as the highest measured concentration in the urbanimpacted reference wetlands (6608 ng/g) but the concentration measured in 2006 was far less (4269 ng/g) (Table 2). In 2006 sediments from both SWQCP and Boundary Ck had higher (98 and
$45 \mathrm{ng} / \mathrm{g}$ respectively) $\sum$ DDT concentrations than all urban-impacted reference wetlands (maximum concentration $44 \mathrm{ng} / \mathrm{g}$ ) (Table 2).

Most wetland sediments were dominated by fine to very fine sands (62.5-250 $\mu \mathrm{m})$. Nepean River, Oyster Bay, Narrabeen, Joseph Banks Park, Bardwell Ck, Galston, Moores Ck, and Chipping Norton had greater than $60 \%$ grains (by weight) N $250 \mu \mathrm{m}$ and sediments at Terrys Ck were dominated by coarse sand to gravel (N500 $\mu \mathrm{m})$. SWQCP, Boundary Ck, Cecil Hills, Haslams Mouth and Kemps Ck, were high in very fine sands and silt (b125 $\mu \mathrm{m})$.

\subsection{Aqueous and sediment TCDDeq}

TCDDeq of the aqueous samples from SOP ranged from $0.014 \mathrm{pM}$ (Narrawang 22) to $0.058 \mathrm{pM}$ (Boundary Ck) (Table 3). In both 2005 and 2006, the average aqueous TCDDeq values were significantly (ANOVA, $\mathrm{F}=0.206, \mathrm{p}=0.010$, Fig. 1) lower in SOP wetlands than in urban reference sites. In the reference sites aqueous TCDDeq values ranged up to $0.097 \mathrm{pM}$ at South $\mathrm{Ck}$ (Table 3). Sediment $\Sigma \mathrm{PCB}$ concentrations explained over $85 \%$ of the variation (i.e., $r^{2}=0.87$ ) in aqueous TCDDeq in 2005 (Table 4). In 2006 and when all collections
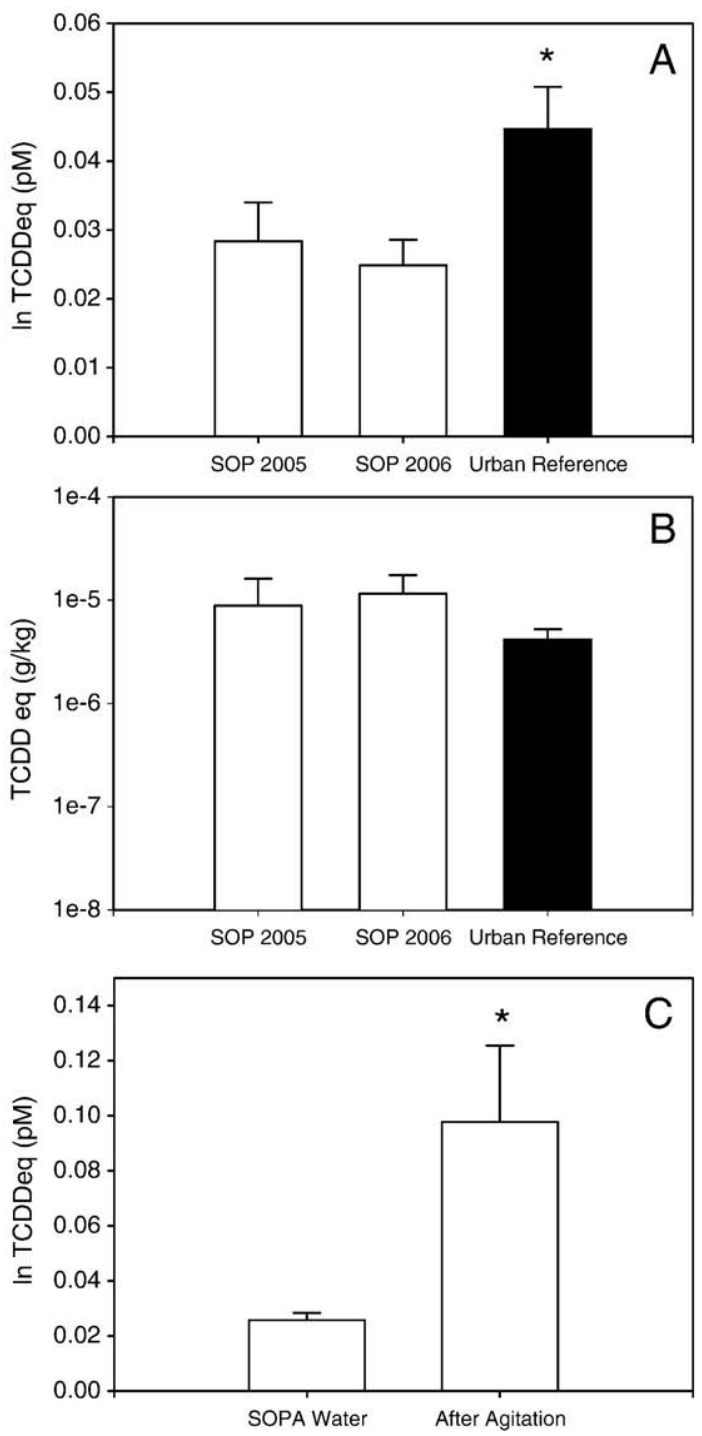

Fig. 1. TCDDeq (measured by the H4IIE cell line bioassay) for A) surface water of Sydney Olympic Park wetlands and urban reference sites; B) sediments at Sydney Olympic Park wetlands and urban reference sites; C) surface water of Sydney Olympic Park wetlands before and after disturbance with sediments. The urban reference collection was made in 2006. *Denotes significantly ( $\mathrm{pb}$ 0.05) different from reference sites or before disturbance. 
Table 4

Results of multiple regressions between TCDDeq values (measured using the H4IIE cell line bioassay) and water and sediment chemical and physico-chemical characteristics.

\begin{tabular}{|c|c|c|c|c|c|c|c|}
\hline & & & F & $\mathrm{P}$ & Predictors & $\begin{array}{l}\text { Corr. } \\
\text { type }\end{array}$ & $r^{2}$ \\
\hline \multirow[t]{12}{*}{ TCDDeq } & \multirow[t]{3}{*}{ Water } & 2005 & 19.62 & 0.021 & $\Sigma \mathrm{PCB}$ & \multirow[t]{3}{*}{+} & \multirow[t]{3}{*}{0.87} \\
\hline & & 2006 & 0.51 & 0.883 & $\mathrm{NSP}^{\mathrm{a}}$ & & \\
\hline & & $\begin{array}{l}2005+ \\
2006\end{array}$ & 0.53 & 0.806 & $\mathrm{NSP}^{\mathrm{a}}$ & & \\
\hline & \multirow[t]{5}{*}{ Sediment } & & & & $\Sigma \mathrm{PCB}$ & + & \\
\hline & & 2005 & 38.31 & 0.000 & $\Sigma \mathrm{DDT}$ & - & \multirow[t]{2}{*}{0.95} \\
\hline & & & & & $\begin{array}{l}\text { Grain size } \\
\text { b0.63 } \mu \mathrm{m}\end{array}$ & + & \\
\hline & & 2006 & 108.80 & 0.000 & $\Sigma \mathrm{PAH}$ & + & 0.80 \\
\hline & & $\begin{array}{l}2005+ \\
2006\end{array}$ & 29.17 & 0.000 & $\Sigma \mathrm{PAH}$ & + & 0.44 \\
\hline & \multirow[t]{4}{*}{ Agitated sediment } & 2006 & 30.21 & 0.004 & Grain size & + & \multirow[t]{4}{*}{0.97} \\
\hline & & & & & $1-2 \mathrm{~mm}$ & & \\
\hline & & & & & Grain size & - & \\
\hline & & & & & $0.25-0.5 \mathrm{~mm}$ & & \\
\hline \multirow{5}{*}{$\begin{array}{l}\text { EROD } \\
\text { activity }\end{array}$} & \multirow[t]{3}{*}{ Contaminant load } & & 14.77 & $0.002^{\mathrm{a}}$ & TCDDeq & + & \multirow[t]{3}{*}{0.79} \\
\hline & & & & & (Water) & & \\
\hline & & & & & Sediment & + & \\
\hline & \multirow{2}{*}{\multicolumn{2}{|c|}{$\begin{array}{l}\text { Sediment grain size } \\
\text { Sediment physico- } \\
\text { chemical parameters }\end{array}$}} & 8.21 & 0.019 & $\begin{array}{l}\text { டrud } \\
1000 \mu \mathrm{m}\end{array}$ & + & \multirow{2}{*}{0.45} \\
\hline & & & - & - & NSP & & \\
\hline
\end{tabular}

NSP $=$ no significant predictors in model.

were combined, differences in aqueous TCDDeq were not significantly (pN0.05) correlated to physical characteristics of the water, or any physical or chemical characteristics of the associated sediment (Table 4).

The TCDDeq of the SOP wetland sediments ranged from $0.016 \mu \mathrm{g} /$ $\mathrm{kg}$ (SWQCP) to $7.06 \mu \mathrm{g} / \mathrm{kg}$ (Bicentennial Park) (Table 3). Homebush Bay and Parramatta River sediments had generally higher TCDDeq values than those at the SOP sites (up to $81.7 \mu \mathrm{g} / \mathrm{kg}$ ) (Table 3). The TCDDeq of SOP wetland sediments were within the range measured in sediments from urban reference sites (0.005-12.9, Table 3 ) and were not significantly different (Fig. 1B). Multiple regression showed correlations between sediment TCDDeq and sediment $\Sigma$ PCBs (positive relationship) and $\Sigma$ DDT (negative relationship) and the amount of fine (b0.63 $\mu \mathrm{m}$ ) sediment grains, which explained 95\% of the variation in 2005 , and with sediment $\Sigma \mathrm{PAH}$ concentration, which explained $80 \%$ of the variation in 2006 (Table 4). When the two collections were combined the sediment $\Sigma \mathrm{PAH}$ concentration accounted for $44 \%$ of the variation in TCDDeq across the study sites (Table 4).

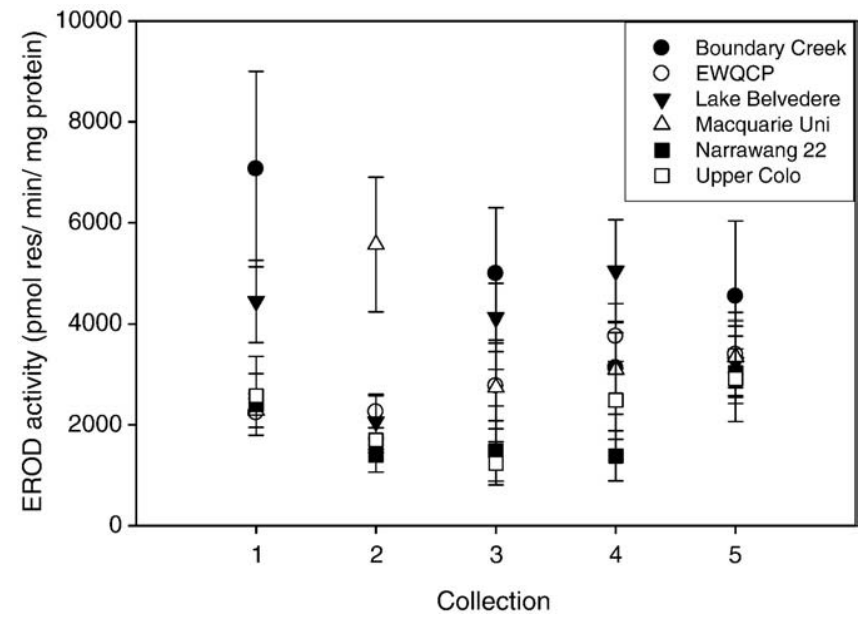

Fig. 2. Mean ( \pm standard error) of hepatic EROD activity in mosquitofish from Sydney Olympic Park and key reference study sites across collection times showing the difference in response at the study sites in the collection just after a high rainfall event (Collection 2).

\subsection{Sediment disturbance}

There was no significant $(p \geq 0.05)$ difference in the TCDDeq after sediment disturbance between disturbance in site and laboratory water; these were subsequently combined. There was a significant (ANOVA, $\mathrm{F}=16.98$, p b0.001, Fig. 1C) increase (3.8-fold) in aqueous TCDDeq after disturbance and multiple regression indicated that differences in sediment grain size (medium to coarse sand) accounted for $97 \%$ of the variation in TCDDeq (Table 4 ).

\subsection{Mosquitofish EROD activity}

Estimated basal hepatic EROD activity for mosquitofish in the Sydney region (average activity in fish from the five collections at the pristine reference site, Upper Colo) was 2308 pmoles res/min/mg protein. There was a significant ( $\mathrm{pb}$ 0.05) interaction between the effects of study site and sampling time on the EROD activity (ANOVA, $\mathrm{F}=2.203, \mathrm{p}=0.007$ ). A plot (Fig. 2) of this interaction (study site vs. sampling) indicated that this interaction could be driven by differences in response at the second collection (made during a high rainfall event). This may be due to either the absence of data for one study site (Boundary $\mathrm{Ck}$ ) or by the spike in readings at Macquarie University. Given that this collection was made during a rainfall event, while all other collections were made without this influence, it was
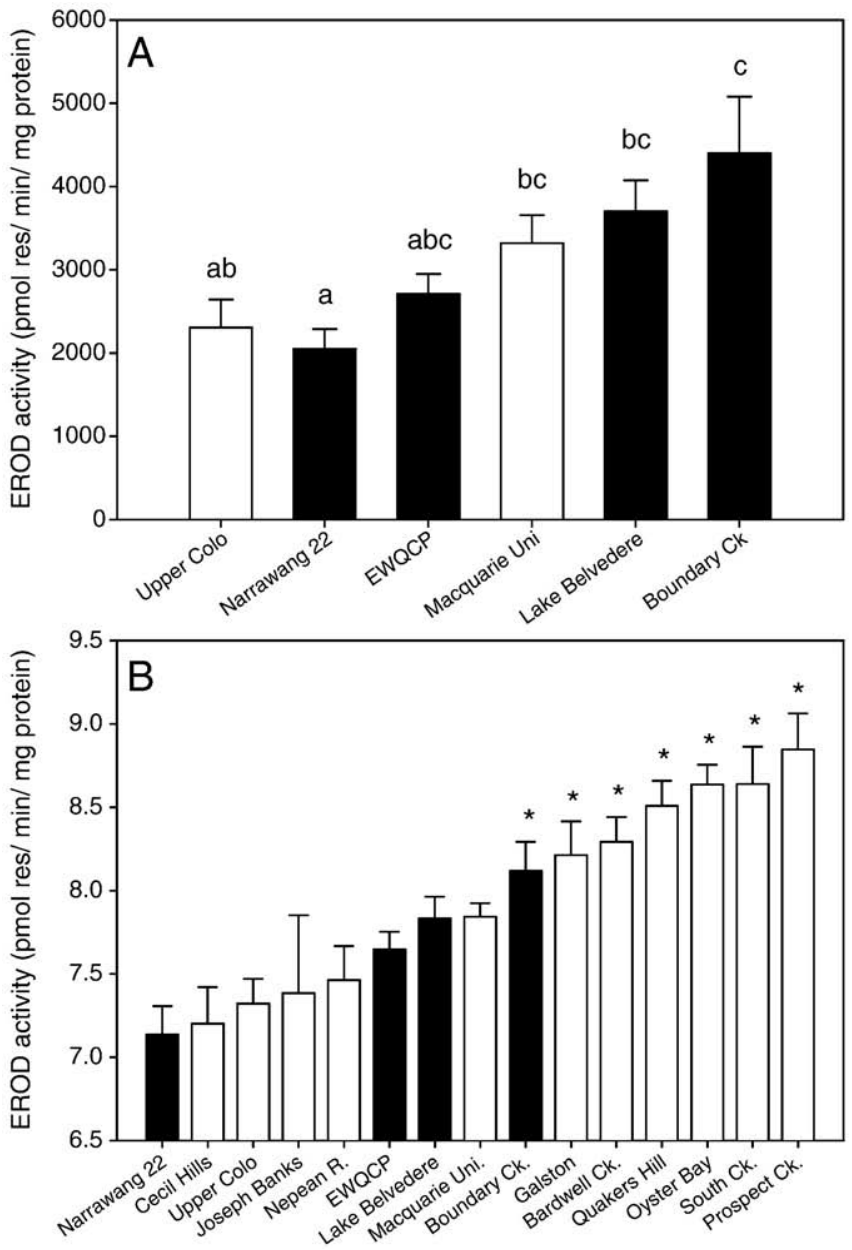

Fig. 3. A. Mean ( \pm standard error) of EROD activity in male mosquitofish inhabiting Sydney Olympic Park wetlands (white bars) and reference sites (black bars). Different letters represent significantly different homogeneous subsets at $\alpha=0.05$. B. Mean ( \pm standard error) for EROD activity in mosquitofish collected in February 2007 from SOP wetlands (black bars) with reference to those from other urban impacted sites around Sydney (white bars). *Significant difference from estimated basal hepatic EROD activity (Upper Colo $=2308$ pmoles res $/ \mathrm{min} / \mathrm{mg}$ protein) at $\alpha=0.05$. 


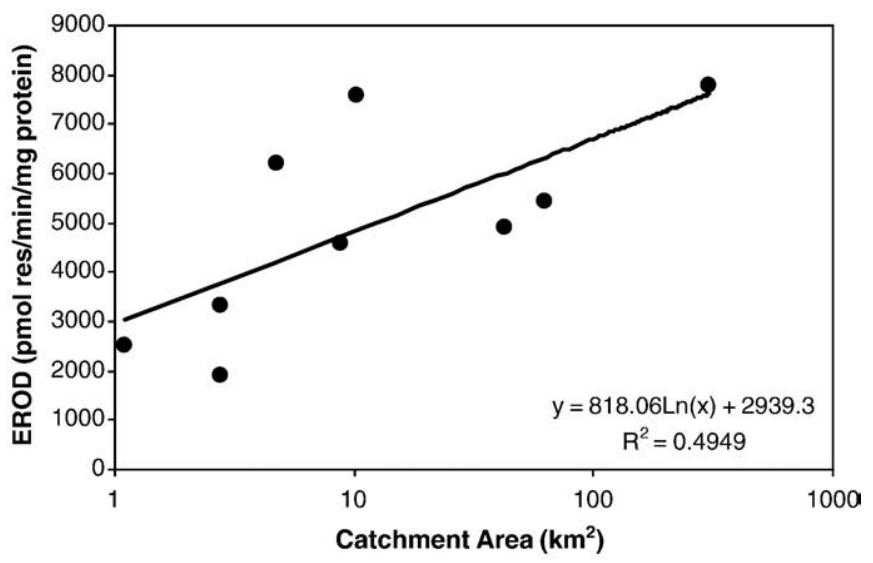

Fig. 4. Relationship between catchment area and EROD activity in adult male mosquitofish at urban impacted reference sites with linear regression equation and coefficient of variation.

decided that this collection should be removed from this part of the analysis. Reanalysing the EROD activity data without this collection removes the significant interaction term and shows that the time of collection did not affect the EROD activity. There was, however, a significant (ANOVA, F $=5.300, \mathrm{pb} 0.001$, Fig. 3A) impact of the site of collection. Fish from only one SOP wetland (Boundary $\mathrm{Ck}$ ) had significantly ( $\mathrm{pb} 0.05$ ) greater EROD activity than the basal level (Fig. 3A). Fish from Lake Belvedere had significantly ( $\mathrm{pb} 0.05$ ) greater EROD activity than those from the created wetland, Narrawang 22 (Fig. 3). The EROD activity in fish from SOP wetlands was toward the lower to middle of the range measured in the urban reference sites (Fig. 3B)with only fish from Joseph Banks Park and Cecil Hills having EROD activity not significantly ( $\mathrm{p} \geq 0.05$ ) greater than the basal level.

The only physical characteristic of the wetlands which was significantly ( $\mathrm{pb} 0.05$ ) correlated to the EROD activity in the fish was the percentage sediment composition of the $1000-\mu \mathrm{m}$ grain size class (positive relationship; $\mathrm{r}^{2}=0.45$ ) (Table 4). The aqueous TCDDeq was significantly ( $\mathrm{pb} 0.05$ ) correlated to EROD activity in mosquitofish. However, an analysis of the power in this regression suggested it was too low (0.61). Changing the significance level for exclusion from the model $(\alpha=0.1)$ gave a model (power N0.9) with significant ( $p$ b 0.1) positive relationships between aqueous TCDDeq and sediment $\Sigma$ PCB load $\left(r^{2}=0.79\right)$ and mosquitofish EROD activity (Table 4).

Populations of fish with higher EROD activity were located in wetlands with large catchment areas (Fig. 4). The exceptions were the two study sites with the largest catchment area (i.e., the Nepean and Upper Colo rivers) which were removed prior to the regression. These sites are located on the outskirts of Sydney and have comparatively low residential landuse. The Nepean River catchment is a mix of minimal land use and natural vegetation used for grazing and the Upper Colo catchment is almost entirely national park.

\section{Discussion}

\subsection{In vitro activity of POPs in SOP wetlands}

Neither the Australian water quality guidelines (ANZECC and ARMCANZ, 2000) nor the USEPA (USEPA, 2006) set a guideline value for PCDDs for the protection of aquatic biota. The current USEPA National Primary Drinking Water Standard for 2,3,7,8-TCDD is $30 \mathrm{pg} / \mathrm{L}$ (0.09 pM) (USEPA, 2003) which is greater than any of the aqueous TCDDeq values measured in the SOP wetlands (maximum $0.058 \mathrm{pM}$ )). Given that drinking water guideline (DWG) criteria are generally many orders of magnitude lower than criteria for protection of aquatic biota (e.g., for total PCBs USEPA WQG $=14 \mathrm{ng} / \mathrm{L}$ and USEPA $\mathrm{DWG}=64 \mathrm{pg} / \mathrm{L}$ ) the aqueous TCDDeq values for the SOP wetlands could be considered of low risk. However, dioxin-like POPs in the dissolved phase may be bioconcentrated by aquatic biota across skin and gill membranes (Verweij et al., 2004) and biomagnified through the food chain. As many of the wetlands examined in the current study are habitat for native species, including the endangered green and golden bell frog, and are primary habitat for wading birds and occasionally larger birds of prey (e.g., white bellied sea eagle) (OCA, 2000), the potential for toxic effects at higher trophic levels necessitates further investigation. However the aqueous TCDDeq was significantly lower in the SOP wetlands than in the urban reference sites, indicating that the risk of this occurring is less within SOP wetlands.

Of concern are the high levels of sediment TCDDeq at the SOP wetland Boundary Ck. Prior to remediation high concentrations of OCPs (50 $\mu \mathrm{g} /$ $\mathrm{kg}$ ) and PAHs (3-5 mg/kg) were measured in Boundary Ck sediments (Laginestra et al., 2001). The concentrations of $\Sigma$ DDT $(45 \mu \mathrm{g} / \mathrm{kg})$ and $\Sigma$ PAHs (3.4 mg/kg) measured in the current study, eight years after the completion of the remediation, are similar to these pre-remediation concentrations. During the remediation works contaminated soil and sediments were removed to a containment mound downstream of the current study site. Due to its position leachate from this mound is unlikely to be contributing new contaminants to the wetland and it is unlikely that contaminated materials left behind would be the source as the stream was geotextile-lined to prevent possible infiltration. The source of this contamination is likely to be storm water from a highly urbanised catchment outside the park. The wetland is designed to remove potentially contaminated suspended particulate matter from the stream (by sedimentation) and prevent its entry into the rest of the Park. The high concentrations reported here may indicate the success of this design; however, the wetland is a significant bird habitat and, therefore, the presence and sources of POP contamination require further investigation.

The high sediment TCDDeq in EWQCP and SWQCP in 2006 (4.58 and $5.2 \mu \mathrm{g} / \mathrm{kg}$, respectively) also requires further investigation. These wetlands were created during the remediation programme to capture and treat surface stormwater and are not adjacent to any waste containment mound. Catchment inputs are, therefore, the likely source of AhR ligands at these wetlands. They are habitat for the endangered green and golden bell frog and also for a number of species of water bird. Together with the Northern Water Feature (sediment TCDDeq = $4.21 \mu \mathrm{g} / \mathrm{kg}$ in 2006), these wetlands are linked to the water recycling system within SOP, which distributes treated water from these sites for irrigation and other non-potable uses within the park. There is, therefore, potential for contaminants at these wetlands to migrate to other areas of the Park and it is recommended that sediment be tested during pond maintenance before treatment or disposal.

The Wharf Stream is a pre-remediation remnant and its catchment previously contained municipal waste dumps but now consists of roads, residential and commercial land, a prison and playing fields. Temporary leachate ponds were constructed adjacent to the stream during the creation of the nearby containment mound. Testing of the sediments around these ponds suggested that there was migration of the leachate from the ponds, but where this occurred the sediment was removed and treated (Laginestra et al., 2001). The possibility that infiltration occurred during this process cannot be ruled out. While the sediments of the wetland are high in TCDDeq, the area is not in high use and the stream flows only at times of high rainfall so the possibility of migration or exposure of biota to contaminants is low.

The differences in sediment TCDDeq values measured in 2005 and 2006 highlights the heterogeneity of the POP concentrations. Spatial heterogeneity in sediment contamination has been described over large (e.g., Johnson and Larsen, 1985; Feng et al., 1998) and small (Koh et al., 2004) spatial scales and differences in contaminant concentrations measured on resampling the same sediments have been reported (e.g., Huggett et al., 1988). While the sampling regime employed in the current study aimed to account for spatial heterogeneity by collecting composite 
samples over a wide area and resampling the same area at different times, it is possible that pockets of more contaminated sediment may be collected and/or missed between sampling times. Alternatively, these differences could be due to contaminated sediment migration to or from the study site caused by wind or increased flow (e.g., tides or stormwater). Although the TCDDeq measured at the SOP wetlands varied between the two sampling times, the average TCDDeq across the sites remained within a similar range. Further, this range was within that measured at the urban reference sites at both sampling times.

\subsection{Mobilisation of AhR ligands through disturbance}

Anthropogenic disturbance can mobilise contaminated sediment (Latimer et al., 1999) and increase the bioavailability of organic contaminants (Rice and White, 1987). Bergen et al. (1998) showed that dredging can cause increased transportation of PCBs for up to 6 months after cessation. The increase in TCDDeq in water samples through disturbance of sediments in the current study supports this and has implications for any further remediation in the area, particularly in Homebush Bay. In February 2006, high levels of dioxins in commercial and recreational fish species linked with contamination of sediment in Homebush Bay led to a ban on fin fishing and prawn trawling in the Port Jackson estuary (Birch et al., 2007). The high levels of TCDDeq reported here in sediment from the mouth of Haslams $\mathrm{Ck}$ and Homebush Bay reflect the known history of uncontrolled dumping and leakage of chemical manufacturing wastes in and around the bay and are consistent with previously reported high concentrations of organic contaminants (Birch and Taylor, 2002; Birch et al., 2007).

In a United Kingdom contaminated lake, Sanders et al. (1992) showed that anoxic conditions can maintain high concentrations of PCBs and DDT in sediments, which reflect historical inputs. Examination of sediment cores taken from Homebush Bay and Parramatta River indicated that the inputs of PAHs and DDTs had decreased over time (USyd, 2001). Higher concentrations of contaminants deeper in the sediment profile is unlikely to be of ecological concern unless remobilised by disturbance (anthropogenic or natural). If the highly POP contaminated sediments in Homebush Bay were disturbed by dredging (scheduled to commence in the very near future) the bioavailability of these POPs, their concentration in body tissues of higher trophic level consumers and their transport throughout the Port Jackson estuary are likely to increase. Equally, there are implications for management of the wetlands of SOP. Disturbance of the wetland sediments should be avoided at times during which sensitive organisms are present (e.g., frog and wading bird breeding season). This should also apply to the disturbance of sediments from other urban-impacted wetlands.

\subsection{Hepatic CYP1A in mosquitofish in SOP wetlands}

CYP1A contributes to detoxification and subsequent elimination of AhR ligands (particularly PAHs) (Denison, 1991; Schmidt and Bradfield, 1996). AhR binding is associated with toxic effects such as carcinogenesis (Schmidt and Bradfield, 1996). The mechanism of AhRmediated toxicity is not well understood but is thought to involve metabolism of procarcinogens to more toxic metabolites (Huff et al., 1994; Whyte et al., 2004). While AhR activation appears to result in cellular oxidative stress (Dalton et al., 2002) and cause sensitivity to cell apoptosis (Nebert et al., 2000), neither the acute nor the chronic effects of increased CYP1A concentrations are well understood. It is necessary, therefore, to view elevated EROD activity as a biomarker of exposure rather than a biomarker of effect. The estimated basal EROD activity in mosquitofish in the Sydney region (based on levels at the pristine Upper Colo site) was towards the upper end of basal levels reported in other species (Whyte et al., 2000).

The only marked difference in EROD activity through time occurred during high rainfall. Urban stormwater can contain a variety of contaminants, such as POPs, depending on the surface and landuse around the catchment (Eriksson et al., 2007). As CYP1A induction is a rapid response (2-4 days) to contaminant exposure (Kloepper-Sams and Stegeman, 1989; Levine and Oris, 1999; Rees et al., 2003) and is rapidly reduced (2-6 days) when the animal is removed from the contaminated environment (Gagnon and Holdway, 2000), differences at the study sites reported here may represent changes in the shortterm availability of POPs to the fish. It is unlikely that these changes were due to dietary uptake as this would not show immediate effect. The catchment runoff to the Macquarie University wetland (which had the highest EROD activity during the second sampling event Fig. 2) may therefore be high in available POPs. The catchment of this wetland is (with the exception of Boundary Ck) more directly impacted by urban development and impermeable surfaces than the SOP wetlands studied here. This may result in contaminated stormwater runoff to the wetland and cause the reported increase in EROD activity in the resident fish. The decrease in EROD activity in fish from Lake Belvedere, Narrawang and Upper Colo upon rain input suggests catchment runoff has low levels of bioavailable POPs and may provide some dilution or flushing effect to the wetlands.

The SOP wetlands, Boundary $\mathrm{Ck}$ and Lake Belvedere, which contained mosquitofish with hepatic EROD activity higher than those at Narrawang 22, represent different remediation histories and current catchment landuse. It is unlikely that the causative contaminants of the higher EROD activities in fish from Boundary Ck. are derived from the park itself given the remediation of this wetland and the fact that the closest containment mound is downstream of the sampling point. It is more likely that the contamination of this wetland originates from its highly urban catchment through stormwater runoff. The high sediment contaminant load and the high EROD induction in fish suggest that this wetland fulfils its role in the sedimentation of suspended particulates; however, migration off-site in the form of bioconcentration in birds or downstream must be considered and avoided. Further, regular testing of the sediment and removal of contaminated sediment is recommended to reduce the exposure of resident biota to POP contamination.

The area surrounding Lake Belvedere was initially remediated in the mid $1980 \mathrm{~s}$ with 30 year-old landfill capped with 1 to $1.5 \mathrm{~m}$ thick imported fill (Laginestra et al., 2001). Subsequent testing of the site in the 1990s indicated significant concern over seepage of contamination from beneath the cap toward surrounding waterways, and studies in 1997 and 1999 identified significant reproductive impairment, PAH and OCP loads and physical malformation (internal and external abscesses) in carp inhabiting the lake (Laginestra et al., 2001). Leachate drains installed during the remediation did not halt the seepage and a new drainage system including a leachate evaporation pond was installed in 1999 (Laginestra et al., 2001). The elevated levels of EROD activity in fish inhabiting Lake Belvedere may either indicate that previously identified problems with seepage has contaminated the sediment of the lake or Boundary Creek inflow has an ongoing impact. While the secondary remediation effort in the immediate surrounds of the lake suggests that it is unlikely, continued leaching of the contained waste remains a possibility. The lake is a designated waterbird refuge so increased exposure to AhR ligands (most of which have high bioconcentration and biomagnification factors) would be of concern. Since the SOP wetland in which mosquitofish had the highest EROD activity (Boundary Ck) flows into Lake Belvedere, and the catchment further upstream is highly urbanised, influx of contaminants from the catchment is likely. Rapid reduction of high $\log \mathrm{K}_{\mathrm{ow}}$ compounds in both the environment (water and sedment) (e.g., PCBs (Imamoglu and Christensen, 2002)) and biological tissue (e.g., 2,3,7,8-TCDD (Crunkilton et al., 1987) and PCBs (Southworth, 1990)) as well as associated biomarkers (e.g., EROD (Wilson et al., 2000)) have been reported downstream of point sources due to rapid binding to sediments. Decreases in the fish EROD activity between Boundary $\mathrm{Ck}$ and Lake Belvedere may reflect the dilution or sedimentation of contaminated particulate matter. 
This is supported by previous studies suggesting that elevated CYP1A induction may be relatively localised to the source. CYP1A inducers decreased downstream (with increasing catchment size) in the Delaware River, away from the severely impacted upper catchment (McCoy et al., 2002). In a study on a marine fish (Platycephalus bassensis) in Port Phillip Bay, Australia, Gagnon and Holdway (2002) found EROD activities in the fish from locations close to the city of Melbourne were generally higher than those from locations in the rest of the Bay. In the current study the positive relationship between hepatic EROD activity and catchment size in the mainly urban impacted sites indicate that the sources of CYP1A inducers are evenly distributed and likely to be the result of urban development rather than the cumulative effect of a series of contaminant point sources.

Low EROD activity in fish from Narrawang 22 provides particularly encouraging information regarding the success of remediation, given its proximity to the largest containment mound in the park and the use of this wetland by wading birds and as primary frog habitat for the green and golden bell frog. The results from Upper Colo were expected as it is located in a relatively pristine region north-west of Sydney isolated from the effects of urbanisation. Its catchment is mainly national park and the possibility of anthropogenic contamination is low with the only possible source being long-range aerial transport and potentially the use of pesticides in the few agricultural land parcels in the region. The fact that there is no evidence of increased EROD activity in fish from EWQCP suggests that the POP contamination of stormwater runoff collected at this site is not available to resident fish populations (relative to the Boundary Ck catchment).

The catchments of the urban reference sites chosen for this study represent a range of landuses. Hoffman et al. (1984) found that wetlands affected by industrial zones and highways had greater PAH inputs than those affected by residential and commercial development and Cavanagh et al. (2000) reported that pikey bream (Acanthopagrus berda) from intensively farmed (sugarcane) regions had 2.5 times the EROD activity of those from undisturbed sites, but a nearby urban-impacted site had double the activity of the sugarcane sites. In the current study, catchment landuse varies from light agricultural (South $\mathrm{Ck}$ ) to highly industrial (Prospect Ck). The wetland with fish with the highest EROD activity (Prospect $\mathrm{Ck}$ ) is a degraded stream with an entirely industrial catchment and wetlands fed by highly urban catchments. It contained fish with greater hepatic EROD activity than catchments with mainly natural vegetation or light agriculture. Industrial and urban activities are important sources of organic contamination in waterways with the major inputs likely to be from aerial deposition (Odabasi et al., 1999) and catchment runoff (Gavens et al., 1982; Ellis et al., 1985).

Aqueous TCDDeq was generally low across all study sites yet appears to influence EROD activity. Most AhR ligands have a high log $\mathrm{K}_{\mathrm{ow}}$ and preferentially bind to the organic fraction of sediments (Gustafsson et al., 1997). Some slightly soluble PAHs and PCB congeners are directly available to aquatic biota across gill surfaces and could be a source of CYP1A inducers here. Sediment $\Sigma$ PCB concentration was also significantly correlated with hepatic EROD activity. This indicates either flux between sediment and aqueous compartments (usually low for PCBs (Achman et al., 1996)) or a biomagnification/dietary effect. While mosquitofish have superior mouths suggesting a surface-feeding habit, their stomach contents (terrestrial and aquatic invertebrates and algal material) indicate that they feed more opportunistically (Pen et al., 1993). While there is conflicting evidence on the ability of poeciliids to bioconcentrate POPs (Yockim et al., 1978; Gobas, 1990; Ford and Hill, 1991; Freidig et al., 1998) it is possible that they are exposed to them through dietary mechanisms where sediment $\Sigma$ PCB concentrations are elevated. The TCDDeq in the sediment was not correlated with the hepatic EROD activity suggesting that while some AhR ligands are bioavailable to the fish (through flux or dietary uptake), others may be either unavailable to benthic biota or do not bioconcentrate in them and, therefore, do not enter the food chain. Sediment POP concentrations in SOP wetlands were generally low compared with globally reported levels so these correlative results should not be seen as an indication of the state of the studied wetlands but rather as an indication of the utility of the hepatic EROD activity of the mosquitofish in examining the bioavailable contaminant (particularly PCBs) load of wetlands.

In the current study there was no correlation between EROD activity and the organic carbon content in the sediments. Increased EROD activity was, however, correlated to the increased proportion of sediment grain size of $1000 \mu \mathrm{m}$. Mechanical disturbance of sediments released AhR ligands into the water and this was also correlated to mid-size sediment grains. While sediment grains of this size may possess a similar organic content to other sediments (neither result was correlated with organic carbon content), POPs may be less tightly bound to mid-size sediments than to finer particles. It is also well established that in urban environments the presence of black carbon in sediments can lead to sequestration of hydrophobic organic contaminants and reduced bioavailavailbility (Ghosh et al., 2003). This indicates the importance of combining organic carbon content, its chemistry and the sediment grain size composition when considering the bioavailability of organic contaminants.

There are no data for the hepatic CYP1A levels in fish inhabiting SOP wetlands prior to remediation making direct comparisons impossible and, given the extremely wide range of basal EROD activity reported in the literature (Whyte et al., 2000) and the speciesspecific induction of CYP1A, it is difficult to make direct comparisons with other remediated sites based on this endpoint. In the current study a four-fold increase above the estimated basal level was the highest observed (fish from the unremediated Prospect Ck). In one of the only studies on this endpoint in a remediated site, Brammell et al. (2004) similarly found a four-fold increase in EROD activity but between a remediated site and a reference site. In the absence of other data it appears that, in terms of this endpoint, the remediation has been adequate. It should be noted that laboratory-based studies have described far greater induction of EROD activity above basal levels. EROD activity in rainbow trout can be increased 172 fold by the PAH $\beta$ naphthoflavone (100 $\mathrm{mg} / \mathrm{kg}$ by i.p. injection) and up to 600 fold by 2,3,7,8-TCDD (0.002 $\mathrm{mg} / \mathrm{kg}$ by i.p. injection) (reviewed by Whyte et al., 2000). These studies do not extrapolate this induction to any physiological effect and caution must be exercised in predicting toxic effects from this endpoint. However it remains a useful biomarker of exposure to many POPs.

4.4. Use of mosquitofish in determination of in vivo and in situ exposure to POPs

Poeciliids have been widely used to investigate the in vivo effects of reproductively active endocrine disrupting compounds (e.g., Doyle

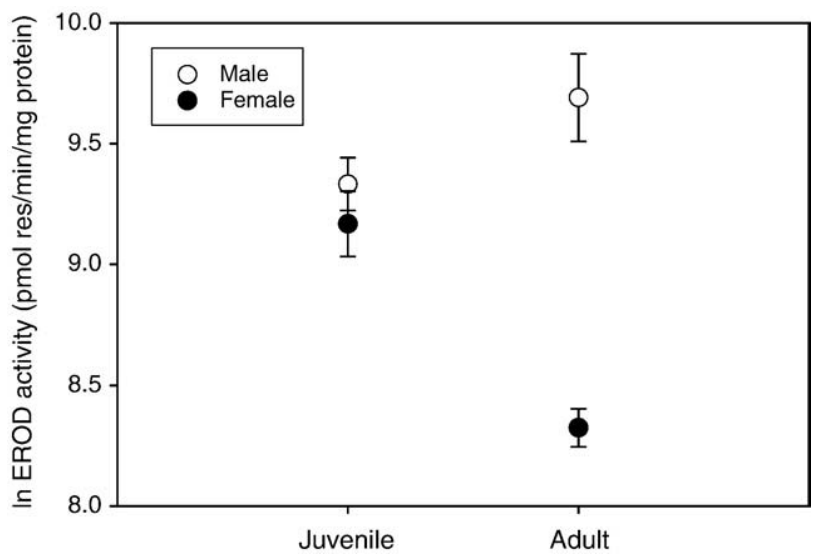

Fig. 5. The interaction between sex and developmental stage of mosquitofish on the induction of CYP1A activity (EROD). 
and Lim, 2002, Angus et al., 2005, Rawson et al., 2008). They are less commonly used to examine the effects and exposure to POPs. POPexposed poeciliids bioconcentrate 2,3,7,8-TCDD (Yockim et al., 1978; Gobas, 1990) and certain PCB congeners (Freidig et al., 1998) but Ford and Hill (1991) found minimal bioconcentration of OCPs. Their small size, ease of capture and opportunistic feeding regime (Pen et al., 1993) makes them particularly suitable for such use. This paper describes appropriate methods for the determination of EROD activity in mosquitofish.

While CYP1A is found in gill, gonad and liver tissues in other species (Whyte et al., 2000), EROD activity could not be reliably measured in mosquitofish gill or gonadal tissue, even with very high reagent concentrations due to the small tissue mass available. Hence, only hepatic EROD activity was investigated in the current study. A pilot study to investigate EROD activity in different sex and developmental stages showed a significant interaction between these factors across sites (ANOVA, $\mathrm{F}=22.68$, p b 0.001, Fig. 5). There was a large decrease in the EROD activity as females developed from juveniles to adults, which was not present in males. In vivo EROD activity in reproductively active mature females (compared with mature males) is reduced as a result of interactions between the estrogen and aryl hydrocarbon receptors (Goksoyr and Larsen, 1991; Elskus et al., 1992; Larsen et al., 1992; Lindstrom-Seppa and Stegeman, 1995; Devaux et al., 1998). The results described above concur with these previous studies with the EROD activity in mature female mosquitofish markedly less than that in mature and immature males and immature females. As it is difficult to distinguish males from females in early life stages the mosquitofish EROD activity should only be compared between sites using sexually mature adult male fish (those with a gonopodial terminal hook complex).

EROD activity has been measured previously in small teleosts (e.g., Japanese medaka (Chen and Cooper, 1999; Carlson et al., 2004)) including poeciliids (e.g., Poecilia reticulata (Larsson et al., 2002)). We have shown that it is possible to measure hepatic CYP1A in wild sexually mature male mosquitofish with no influence of season and, by implication, reproductive state. This suggests that these are appropriate organisms in which to investigate exposure to POPs via EROD activity in Australian freshwater wetlands. The difference between sites in the influence of rainfall on hepatic EROD activity indicates that sampling during and immediately following suspected contaminant influx should be considered separately from chronic exposure through the food chain measured during steady state and can provide valuable information on stormwater quality.

\section{Conclusions}

This study demonstrates the success of the remediation program in reducing POP contamination at most of the SOP wetlands to within the chemical bounds expected from urban wetlands in Sydney, Australia, and indicates the heavy influence of catchment-based contamination sources. There is a particular need for the ongoing monitoring of the concentrations of POPs in Boundary Creek, EWQCP, SWQCP and the Northern Water Feature. The importance of avoiding the disturbance of wetland sediments, thereby minimising mobile and bioavailable contaminants is stressed. The correlation between hepatic EROD activity and aqueous TCDDeq but not sediment TCDDeq suggests the importance of direct exposure of the mosquitofish to POPs compared to dietary intake. However the correlation between EROD activity and sediment $\Sigma$ PCBs indicates the importance of this group of POPs and a field for further study. The investigation of potential effects at higher levels of biological organisation (e.g., population and community) is necessary in order to fully assess the ecological risk POPs pose in Sydney Olympic Park or other urban wetlands.

\section{Acknowledgements}

This research was funded by an Australian Research Council (ARC) Linkage Grant (LP0455131) awarded to UTS. Research was conducted with the approval of the UTS/RNSH Animal Care and Ethics Committee (UTS/RNSH Protocol no. 0002-011A). The authors wish to thank Christine Bezar for her comments on the manuscript.

\section{References}

Achman DR, Brownawell BJ, Zhang L. Exchange of polychlorinated biphenyls between sediment and water in the Hudson River estuary. Estuaries 1996;19:950-65.

Angus RA, Stanko J, Jenkins RL, Watson RD. Effects of 17a-estradiol on sexual development of male western mosquitofish (Gambusia affinis). Comp Biochem Physiol C 2005;140:330-9.

ANZECC and ARMCANZ. Australian and New Zealand Guidelines for Fresh and Marine Water Quality. Australian and New Zealand Environmental and Conservation Council and Agricultural and Resource Management Council of Australia and New Zealand; 2000.

Barsotti DA, Abrahamson LJ, Allen JR. Hormonal alterations in female rhesus monkeys fed a diet containing 2,3,7,8-tetrachlorodibenzo-p-dioxin. Arch Environ Contam Tox 1979;21:463-9.

Bergen BJ, Rahn KA, Nelson WG. Remediation at a marine superfund site: surficial sediment PCB congener concentration, composition and redistribution. Environ Sci Technol 1998;32:3496-501.

Birch G, Taylor S. Possible biological significance of contaminated sediments in Port Jackson, Sydney, Australia. Environ Monit Assess 2002;77:179-90.

Birch GF, Harrington C, Symons RK, Hunt JW. The source and distribution of polychlorinated dibenzo-p-dioxin and polychlorinated dibenzofurans in sediments of Port Jackson, Australia. Mar Pollut Bull 2007;54:295-308.

Brammell BF, Price DJ, Birge WJ, Elskus AA. Apparent lack of CYP1A response to high PCB body burdens in fish from a chronically PCB contaminated site. Mar Environ Res 2004;58:251-5.

Burke MD, Mayer RT. Ethoxyresorufin: direct fluorometric assay of a microsomal O-dealkylation which is preferentially inducible by 3-methylcholanthrene. Drug Metab Dispos 1974;2:583-8.

Carlson EA, Li Y, Zelikoff JT. Benzo[a]pyrene-induced immunotoxicity in Japanese medaka (Oryzias latipes): relationship between lymphoid CYP1A activity and humoral immune suppression. Toxicol Appl Pharm 2004;201:40-52.

Cavanagh JE, Burns KA, Brunskill GJ, Ryan DAJ, Ahokas JT. Induction of hepatic cytochrome P-4501A in pikey bream (Acanthopagrus berda) collected from agricultural and urban catchments in far north Queensland. Mar Pollut Bull 2000;41:377-84.

Chen CM, Cooper KR. Developmental toxicity and EROD induction in the Japanese medaka (Oryzias latipes) treated with dioxin congeners. Arch Environ Contam Tox 1999;63:423-9.

Crunkilton RL, Smith LM, Petty JD, Kloepfer RD. Residues of 2,3,7,8-tetrachlorodibenzop-dioxin in the Spring River, Missouri. Water Air Soil Poll 1987;32:219-31.

Dalton TP, Puga A, Shertzer HG. Induction of cellular oxidative stress by aryl hydrocarbon receptor activation. Chem-Biol Interact 2002;141:77-95.

Delzell E, Doull J, Giesy JP, Mackay D, Munro I, Williams G. Potential adverse effects of chlorinated chemicals; Appendix J: Polychlorinated dibenzo-p-dioxins and polychlorinated dibenzofurans. Regul Toxicol Pharm 1994a;20:S960-S1029.

Delzell E, Doull J, Giesy JP, Mackay D, Munro I, Williams G. Potential adverse effects of chlorinated chemicals; Chapter 4: Pesticides. Regul Toxicol Pharm 1994b;20: S160-86.

Delzell E, Doull J, Giesy JP, Mackay D, Munro I, Williams G. Potential adverse effects of chlorinated chemicals; Chapter 5: Polychlorinated biphenyls. Regul Toxicol Pharm 1994c;20:S187-307.

Denison MS. The molecular mechanism of action of 2,3,7,8-tetrachlorodibenzo-p-dioxin and related halogenated aromatic hydrocarbons. Chemosphere 1991;23:1825-30.

Denison MS, Heath-Pagliuso S. The Ah receptor: a regulator of the biochemicaland toxicological actions of structurally diverse chemicals. Arch Environ Contam Tox 1998;61:557-68.

Devaux A, Flammarion P, Bernardon V, Garric J, Monod G. Monitoring of the chemical pollution of the River Rhone through measurement of DNA damage and cytochrome P4501a induction in chub (Leuciscus cephalus). Mar Environ Res 1998;46:257-62

Doyle CJ, Lim RP. The effect of 17b-estradiol on the gonopodial development and sexual activity of Gambusia holbrooki. Environ Toxicol Chem 2002;21:2719-24.

Eggens ML, Galgani F. Ethoxyresorufin-O-deethylase (EROD) activity in flatfish: fast determination with a fluorescence plate-reader. Mar Environ Res 1992;33:213-21.

Ellis JB, Revitt DM, Gavens A. Polyaromatic hydrocarbon distributions in sediments of an urban catchment. Int J Environ Anal Chem 1985;21:161-70.

Elskus AA, Pruell RJ, Stegeman JJ. Endogenously mediated pretranslational suppression of cytochrome P4501A in PCB contaminated flounder. Mar Environ Res 1992;34:97-101.

Eriksson E, Baun A, Scholes L, Ledin A, Ahlman S, Revitt M, et al. Selected stormwater priority pollutants - a European perspective. Sci Total Environ 2007;383:41-51.

Feng H, Cochran JK, Lwiza H, Brownawell BJ, Hirschberg DJ. Distribution of heavy metal and PCB contaminants in the sediments of an urban estuary: the Hudson River. Mar Environ Res 1998;45:69-88. 
Finizio A, Vighi M, Sandroni D. Determination of n-octanol/water partition coefficient (Kow) of pesticide: critical review and comparison of methods. Chemosphere 1997;34:131-61.

Ford WM, Hill EP. Organochlorine pesticides in soil sediments and aquatic animals in the Upper Steele Bayou watershed of Mississippi. Arch Environ Contam Tox 1991;20:161-7.

Freidig AP, Garicano EA, Busser FJM, Hermens JLM. Estimating impact of humic acid on bioavailability and bioaccumulation of hydrophobic chemicals in guppies using kinetic solid-phase extraction. Environ Toxicol Chem 1998;17:998-1004.

Gagnon MM, Holdway DA. EROD induction and biliary metabolite excretion following exposure to the water accommodated fraction of crude oil and to chemically dispersed oil. Arch Environ Con Tox 2000;38:70-7.

Gagnon MM, Holdway DA. EROD activity, serum SDH and PAH biliary metabolites in sand flathead (Platycephalus bassensis) collected in Port Phillip Bay, Australia. Mar Pollut Bull 2002;44:230-7.

Gavens A, Revitt DM, Ellis JB. Hydrocarbon accumulation in freshwater sediments of an urban catchment. Hydrobiologia 1982;91:285-92.

Ghosh U, Zimmerman JR, Luthy RG. PCB and PAH speciation among particle types in contaminated harbour sediments and effects on PAH bioavailability. Environ Sci Technol 2003;37:2209-17.

Gobas FAPC. Bioaccumulation of some polychlorinated dibenzo-p-dioxins and octachlorodibenzofuran in the guppy (Poecilia reticulata). Chemosphere 1990;20:495-512.

Goksoyr A, Larsen HE. The cytochrome P450 system of atlantic salmon (Salmo salar): I. basal properties and induction of P450 1A1 in liver of immature and mature fish. Fish Physiol Biochem 1991;9:339-49.

Gustafsson O, Haghseta F, Chan C, Macfarlane J, Gschwend PM. Quantification of the dilute sedimentary soot phase: implications for PAH speciation and bioavailability Environ Sci Technol 1997;31:203-9.

Hahn ME. The aryl hydrocarbon receptor: a comparative review. Comp Biochem Phys C 1998; $121: 23-53$

Hansen BG, Paya-Perez AB, Rahman M, Larsen BR. QSARs for Kow and Koc of PCB congeners: a critical examination of data, assumptions and statistical approaches. Chemosphere 1999;39:2209-28.

Hoffman EJ, Mills GL, Latimer JS, Quinn JG. Urban runoff as a source of polycyclic aromatic hydrocarbons to coastal waters. Environ Sci Technol 1984;18:580-7.

Huff J, Jucier G, Tritscher A. Carcinogenicity of TCDD: experimental, mechanistic and epidemiologic evidence. Annu Rev Pharmacol Toxicol 1994;34:343-72.

Huggett RJ, de Fur PO, Bieri RH. Organic compounds in Chesapeake Bay sediments. Mar Pollut Bull 1988;19:454-8.

Imamoglu I, Christensen ER. PCB sources, transformations, and contributions in recent Fox River, Wisconsin sediments determined from receptor modeling. Water Res 2002;36:3449-62.

Johnson AC, Larsen PF. The distribution of polycyclic aromatic hydrocarbons in the surficial sediments of Penobscot Bay (Maine, USA) in relation to possible sources and to other sites worldwide. Mar Environ Res 1985;15:1-16.

Kloepper-Sams PJ, Stegeman JJ. The temporal relationships between P450E protein content, catalytic activity and mRNA levels in the teleost Fundulus heteroclitus following treatment with b-naphthoflavone. Arch Biochem Biophys 1989;268:525-35.

Koh CH, Khim JS, Kannan K, Villeneuve DL, Senthilkumar K, Giesy JP. Polychlorinated dibenzo-p-dioxins (PCDDs), dibenzofurans (PCDFs), biphenyls (PCBs), and polycyclic aromatic hydrocarbons (PAHs) and 2,3,7,8-TCDD equivalents (TEQs) in sediment from the Hyeongsan River, Korea. Environ Pollut 2004;132:489-501.

Laginestra E, Slattery E, Statzenko A. Sydney Olympic Park: Post Remediation Reference Manual, 2001. Sydney, Australia: Sydney Olympic Park Authority (SOPA); 2001. p. 415.

Larsen HE, Celender M, Goksoyr A. The cytochrome P450 system of atlantic salmon (Salmo salar): II. Variations in hepatic catalytic activities and isozyme patterns during an annual reproductive cycle. Fish Physiol Biochem 1992;10:291-301.

Larsson DGJ, Kinnberg K, Sturve J, Stephensen E, Skon M, Forlin L. Studies of masculinisation, detoxification and oxidative stress responses in guppies (Poecilia reticulata) exposed to effluent from a pulp mill. Ecotoxicol Environ Saf 2002;52:13-20.

Latimer JS, Davis WR, Keith DJ. Mobilisation of PAHs and PCBs from in-place contaminated marine sediments during simulated resuspension events. Estuar Coast Shelf Sci 1999;49:577-95.

Levine SL, Oris JT. CYP1A expression in liver and gill of rainbow trout following waterborne exposure: implications for biomarker determination. Aquat Toxicol 1999;46:279-87.
Lindstrom-Seppa P, Stegeman JJ. Sex differences in cytochrome P4501A induction in environmental exposure and b-naphthoflavone in liver and extrahepatic organs of recrudescent winter flounder. Mar Environ Res 1995;39:219-23.

McCoy DL, Jones JM WAJ, Harmon M, Hartwell I, Hameed J. Distribution of cytochrome P4501A1-inducing chemicals in sediments of the Delaware River-Bay system. Environ Toxicol Chem 2002;21:1618-27.

Nebert DW, Roe AL, Dieter MZ, Solis WA, Yang Y, Dalton TP. Role of the aromatic hydrocarbon receptor and $[\mathrm{Ah}]$ gene battery in the oxidative stress response, cell cycle control and apoptosis. Biochem Pharmacol 2000;59:65-85.

OCA. Compendium of ESD initiatives and outcomes for OCA facilities and venues. 1 Ed. Sydney: Olympic Coordination Authority; 1997.

OCA. Five Sentinel species: Restoration Ecology at Millenium Parklands. Sydney: Olympic Coordination Authority; 2000. p. 7.

OCA and ADI. Summary of treatment of scheduled chemical waste at North Homebush Bay by indirect thermal desorption (ITD) and base catalyzed decomposition process (ADOX/BCD). Olympic Coordination Authority, Australian Defence Industries, Ltd. Sydney; 1999. Document Number ST6650. Issue 1.2.

Odabasi M, Sofuoglu A, Vardar N, Tasdemir Y, Holsen TM. Measurement of dry deposition and air-water exchange of polycyclic aromatic hydrocarbons with the water surface sampler. Environ Sci Technol 1999;33:426-34.

Oropeza-Hernandez LF, Lopez-Romero R, Albores A. Hepatic CYP1A, 2B, 2C, 2E and 3A regulation by methoxychlor in male and female rats. Toxicol Lett 2003;144:93-103.

Pen LJ, Potter IC, Calver MC. Comparisons of the food niches of three native and two introduced fish species in an Australian river. Environ Biol Fish 1993;36:167-82.

Rawson CA, Lim RP, Warne MSJ. The skeletal morphology and maturation of male Gambusia holbrooki exposed to sewage treatment plant effluent. Ecotoxicol Environ Saf 2008;70:453-61.

Rees CB, McCormick SD, van den Heuvel JP, Li W. Quantitative PCR analysis of CYP1A induction in atlantic salmon (Salmo salar). Aquat Toxicol 2003;62:67-78.

Rice CP, White DS. PCB availability assessment of river dredging using caged clams and fish. Environ Toxicol Chem 1987;6:259-74.

Rubenstein N, Wicklund J. Dioxin contamination of sediment and marine fauna in Homebush Bay. Sydney: State Pollution Control Commission; 1991. p. 12.

Sanders G, Jones KC, Hamilton-Taylor J. Historical inputs of polychlorinated biphenyls and other organochlorines to a dated lacustrine sediment core in rural England. Environ Sci Technol 1992;26:1815-21.

Schmidt JV, Bradfield CA. Ah receptor pathways. Annu Rev Cell Dev Biol 1996;12:55-89.

Sierra-Santoyo A, Hernandez M, Albores A, Cebrian ME. Sex-dependent regulation of hepatic cytochrome P-450 by DDT. Toxicol Sci 2000;54:81-7.

SKM and EVS. Ongoing toxicity monitoring of leachate. Sydney: Sydney Olympic Park Authority; 2001. p. 102.

Southworth GR. PCB concentrations in stream sunfish (Lepomis auritus and L. macrochirus) in relation to proximity to chronic point sources. Water Air Soil Pollut 1990;51:287-96.

USEPA. National primary drinking water standards. United States Environmental Protection Agency, Office of Water; 2003. p. 6.

USEPA. National Recommended Water Quality Criteria. United States Environmental Protection Agency, Office of Water, Office of Science and Technology; 2006.

USyd TEGG. Olympic Co-ordination Authority Sediment Coring Project. The Olympic Coordination Authority; 2001.

Verweij F, Booij K, Satumalay K, van der Molen N, van der Oost R. Assessment of bioavailable PAH, PCB and OCP concentrations in water, using semipermeable membrane devices (SPMDs), sediments and caged carp. Chemosphere 2004;54:1675-89.

Waste Services NSW. The Homebush Bay olympic site: Preparing the ground. Sydney: Waste Services NSW; 1994.

Whyte JJ, Jung RE, Schmitt CJ, Tillitt DE. Ethoxyresorufin-O-deethylase (EROD) activity in fish as a biomarker of chemical exposure. Crit Rev Toxicol 2000;30:347-571. Whyte JJ, Schmitt CJ, Tillitt DE. The H4IIE cell bioassay as an indicator of dioxin-like chemicals in wildlife and the environment. Crit Rev Toxicol 2004;34:1-83.

Wilson JY, Addison RF, Martens D, Gordon R, Glickman B. Cytochrome P450 1A and related measurements in juvenile chinook salmon (Oncorhynchus tshawytscha) from the Fraser River. Can J Fish Aquat Sci 2000;57:405-13.

Ying, G.-G., Rawson, C., Kookana, R.S., Lim, R.P., Warne, M.S.J., Zhou, J.L. et al., in preparation. Distribution and sources of inorganic and organic contaminants in sediments from Sydney Olympic Park and the surrounding Sydney metropolitan area.

Yockim RS, Isensee AR, Jones GE. Distribution of TCDD and 2,4,5-T in an aquatic model ecosystem. Chemosphere 1978;3:215-20. 